\title{
In vitro propagation of Santalum album L.
}

\author{
M.K.P. Peeris and W.T.P.S.K. Senarath* \\ Department of Botany, Faculty of Applied Science, University of Sri Jayewardenepura, Gangodawila, Nugegoda.
}

Revised: 04 March 2015; Accepted: 25 March 2015

\begin{abstract}
Santalum album L. (sandalwood) is a valuable tropical plant species that belongs to the family Santalaceae. Santalol - the active compound in S. album, which is commonly known as sandalwood oil is highly valued in the perfumery industry due to its sweet persistent aroma. Sandalwood plants are over-exploited for harvesting their wood. Although the species is naturally regenerated by seeds the success rate is as low as $20 \%$. Due to the hemi-parasitic nature of S. album, the survival of seedlings is low making the species rare in Sri Lanka. There is a high demand for sandalwood plants for commercial scale plantations. Therefore in the present study, plantlet regeneration through somatic embryogenesis was studied in order to produce a large number of healthy plants to be used in establishing commercial scale plantations.
\end{abstract}

Mature and immature seeds, leaf discs and nodal segments were used as explants for embryonic callus induction. Nodal segments found to be the best explants for embryonic callus production. Murashige and Skoog medium (MS) supplemented with $2.5 \mathrm{mg} / \mathrm{L}$ 2,4-dichloro phenoxy acetic acid (2,4-D) and $3.0 \mathrm{mg} / \mathrm{L}$ kinetin (kin) induced callus with a mean diameter of $3.22 \pm 0.1 \mathrm{~cm}$ after 8 weeks of incubation. Somatic embryo induction was optimized by the addition of $0.5 \mathrm{mg} / \mathrm{L}$ benzyl amino purine (BAP), $1.0 \mathrm{mg} / \mathrm{L}$ indole-3-acetic acid (IAA) and $0.5 \mathrm{mg} / \mathrm{L}$ kin to MS medium, which resulted about 10 somatic embryos per $1.0 \mathrm{~cm}^{2}$ of callus. Somatic embryos germinated best in MS medium supplemented with $2.0 \mathrm{mg} / \mathrm{L}$ gibberellic acid $\left(\mathrm{GA}_{3}\right)$. The highest percentage of plantlet regeneration was observed when the germinated embryos were transferred into MS medium supplemented with $0.4 \mathrm{mg} / \mathrm{L} \mathrm{BAP}$ and $0.2 \mathrm{mg} / \mathrm{L}$ IAA.

Keywords: Plantlet regeneration, Santalum album, somatic embryogenesis.

\section{INTRODUCTION}

Santalum album (sandalwood) is a valuable tropical plant species, which belongs to the family Santalaceae (Rai, 1990). It is native to the Indian sub-continent. $S$. album has been a part of the Sri Lankan culture since ancient times and has been synonymous with ancient Indian culture and heritage (Mujib, 2005). Sri Lanka is reported as one of the exporters of sandalwood to various countries (Srinivasan et al., 1992). Santalol - the active compound in S. album - is known as sandalwood oil and is highly valued in the perfumery industry due to its sweet, persistent aroma and the fixative property (Jain et al., 2003). The plants that grow naturally are over-exploited for harvesting wood to obtain santalol and also for other purposes such as to use in wood carving industries and indigenous medicine. These activities contribute towards the destruction of S. album plants in Sri Lanka.

In nature, sandalwood is propagated by seeds. However, the success rate of seed germination is very low (Viswanath et al., 2009). The viability of seeds is lost within six to nine months of storage. Therefore, developing an in vitro protocol for mass propagation of this valuable species is important to produce high yielding homozygous clones for establishing sandalwood plantations.

Regeneration of S. album via somatic embryogenesis has been achieved from hypocotyl, nodal and endosperm explants with low success rates (less than $5 \%$ ) (Lakshmi et al., 1979; Rao \& Bapat, 1992). However, the 
procedures reported take more than 10 months or more for the development of plantlets.

Therefore, the objective of the present study was to develop a successful rapid protocol for the regeneration of $S$. album through tissue culture using elite trees.

\section{METHODS AND MATERIALS}

Explants were collected from a two-year old mother stock maintained in the shade house. Fungicide (Tilt, $10.0 \mathrm{~mL} / \mathrm{L}$ ) was sprayed once a week to reduce the contamination in cultures; Topsin $(5.0 \mathrm{~g} / \mathrm{L})$ and Thiram $(1.4 \mathrm{~g} / \mathrm{L})$ was sprayed alternatively to the mother stock. Albert solution was applied (50.0 mL per plant) weekly. As $S$. album is a hemi parasitic plant, buffalo grasses, Desmodium sp. and Alternanthera sp. were planted in pots with sandalwood seedlings. Explants were collected in the morning, washed in soap water for 5 min and kept under running tap water for $30 \mathrm{~min}$. They were dipped in a solution of Captan ${ }^{\mathrm{Tm}}(2.0 \mathrm{~g} / \mathrm{L})$ for $30 \mathrm{~min}$. The explants were then washed in $15 \%$ Clorox $^{\mathrm{Tm}}$ for $15 \mathrm{~min}$, followed by $70 \%$ ethanol for $10 \mathrm{~min}$, each followed by three successive washings in sterile distilled water.

Murashige and Skoog (MS) medium (Murashige \& Skoog, 1962) was used as the basal medium and the $\mathrm{pH}$ was adjusted to 5.8. Commercial jelly moss $(8.0 \mathrm{~g} / \mathrm{L})$ was used as the solidifying agent to reduce the cost per plant. Cultures were incubated at $25 \pm 1{ }^{\circ} \mathrm{C}$. Complete randomized design (CRD) was used in all experiments with 20 replicates in each treatment. Results were analysed using the MINITAB statistical package.

\section{Determination of best explant source for embryonic callus induction}

For the selection of best explant source for callus initiation, $2.0 \mathrm{~cm}$ long nodal segments $\left(2^{\text {nd }}\right.$ and $3^{\text {rd }}$ nodal segment from the meristem) and mature and immature seeds (where the pericarp is green and still attached to the plant and leaf discs $)\left(1.0 \mathrm{~cm}^{2}\right)$ were used. After surface sterilisation they were cultured in MS medium supplemented with $2.5 \mathrm{mg} / \mathrm{L} 2,4$-dichloro phenoxy acetic acid (2,4-D) and $3.0 \mathrm{mg} / \mathrm{L}$ kin and incubated in the dark at $25 \pm 1{ }^{\circ} \mathrm{C}$. Growth regulator free MS medium was used as the control. Mean callus diameter and the percentage of callus production were measured. Data were collected at 2 week intervals.

Determination of best growth regulator combination for embryonic callus induction from nodal segments

Surface sterilised nodal segments (single noded) were cultured in MS medium supplemented with
2,4 -D (1.0 - 3.5 mg/L) and kin ( $1.0-3.5 \mathrm{mg} / \mathrm{L})$. Growth regulator free MS medium was used as the control. Cultures were incubated in dark at $25 \pm 1{ }^{\circ} \mathrm{C}$. Callus diameter was measured at every 2 week intervals over a period of 8 weeks.

Determination of best growth regulator combination for embryo induction

Six-week old fragile, translucent calli derived from nodal segments were used in this experiment. The calli $\left(\sim 1.0 \mathrm{~cm}^{2}\right)$ were transferred to MS medium supplemented with different combinations of kin $(0.25-1.00 \mathrm{mg} / \mathrm{L})$, indole-3-acetic acid (IAA) $(0.25-1.00 \mathrm{mg} / \mathrm{L})$ and benzyl amino purine (BAP) $(0.25-0.50 \mathrm{mg} / \mathrm{L})$. Growth regulator free MS medium was used as the control. Cultures were incubated in dark at $25 \pm 1{ }^{\circ} \mathrm{C}$. The number of induced somatic embryos per callus $\left(\sim 1.0 \mathrm{~cm}^{2}\right)$ was counted at every 2 week intervals over a period of 8 weeks.

\section{Determination of best growth regulator combination for somatic embryo germination}

In vitro induced embryos from calli derived from nodal segments were transferred into MS medium supplemented with a concentration range of gibberellic acid $\left(\mathrm{GA}_{3}\right),(0.5$ $\mathrm{mg} / \mathrm{L}-2.5 \mathrm{mg} / \mathrm{L})$. Growth regulator free medium was used as the control. Cultures were incubated under $16 \mathrm{~h}$ photoperiod at $25 \pm 1{ }^{\circ} \mathrm{C}$ over a period of 8 weeks. The percentage of somatic embryo germination was observed at every 2 week intervals.

Determination of best growth regulator combination for plantlet development from germinated somatic embryos

In vitro germinated somatic embryos were transferred to MS medium supplemented with a range of BAP $(0.2-0.6 \mathrm{mg} / \mathrm{L})$ and IAA $(0.1-0.4 \mathrm{mg} / \mathrm{L})$. Growth regulator free MS medium was used as the control. Cultures were incubated under $16 \mathrm{~h}$ photoperiod at $25 \pm 1{ }^{\circ} \mathrm{C}$. The number of plantlets developed was counted at every 2 week intervals over a period of 8 weeks.

\section{RESULTS AND DISCUSSION}

\section{Determination of best explant source for embryonic callus induction}

In the present study, all the explant types tested produced calli in MS medium supplemented with $2.5 \mathrm{mg} / \mathrm{L} \mathrm{2,4-D}$ and $3.0 \mathrm{mg} / \mathrm{L} \mathrm{kin}$, at $25 \pm 1{ }^{\circ} \mathrm{C}$ in the dark. The calli were pale cream in colour and had fragile, translucent texture (Figure 1a). 
No callus induction was observed in growth regulator free MS medium (control). Analysis of variance indicated that there was a significant difference between the mean callus diameters and the percentages of callus induction in different explants. Percentage callus induction was higher in nodal segments (95.64 $\pm 0.12)$ and in mature seeds $(95.34 \pm 0.11)$. However, after 8 weeks of incubation the highest callus diameter $(2.48 \pm 0.15 \mathrm{~cm})$ was obtained from the nodal segments and the values were significantly higher than all other tested explant types. Leaf discs cultured on the same medium showed the second highest callus diameter $(0.82$ $\pm 0.10 \mathrm{~cm}$ ) (Table 1). Although mature seeds showed the second highest percentage of callus production, the mean callus diameter was significantly low $(0.53 \pm 0.05 \mathrm{~cm})$ (Figure 1b). The results obtained suggest that nodal segments are the best explant source to obtain fragile, translucent calli of $S$. album.

Table 1: Mean callus diameter obtained with different explant sources cultured on MS medium supplemented with $2.5 \mathrm{mg} / \mathrm{L} 2,4-\mathrm{D}$ and $3.0 \mathrm{mg} / \mathrm{L}$ kin after eight weeks of incubation at $25 \pm 1{ }^{\circ} \mathrm{C}$ in complete darkness

\begin{tabular}{lcc}
\hline Explant type & $\begin{array}{c}\text { Mean callus diameter } \pm \text { SE } \\
(\mathrm{cm})\end{array}$ & \% callus induction \\
\hline Nodal segments & $2.48 \pm 0.05^{\mathrm{a}}$ & $95.64 \pm 0.12$ \\
Immature seeds & $0.54 \pm 0.07^{\mathrm{b}}$ & $85.52 \pm 0.09^{\mathrm{d}}$ \\
Mature seeds & $0.53 \pm 0.05^{\mathrm{b}}$ & $95.34 \pm 0.11$ \\
Leaf discs & $0.82 \pm 0.1^{\mathrm{C}}$ & $85.32 \pm 0.17^{\mathrm{d}}$ \\
LSD & 0.11 & 0.13 \\
\hline
\end{tabular}

${ }^{*}$ Measurements are the means of twenty replicates $\pm \mathrm{SE}$

${ }^{*}$ Means within the columns with the same letter are not significantly different

\section{Determination of best growth regulator combination for embryonic callus induction from nodal segments}

Fragile, translucent callus initiation from nodal explants was observed in all the tested treatments after 10 days of incubation in dark. No callus induction was observed in the growth regulator free MS medium. There was a significant difference between the mean callus diameters in different treatments.

After 8 weeks of incubation the highest mean callus diameter $(3.22 \pm 0.1 \mathrm{~cm})$ was observed in MS medium supplemented with $2.5 \mathrm{mg} / \mathrm{L} 2,4-\mathrm{D}$ and 3.0 $\mathrm{mg} / \mathrm{L}$ kin, which was significantly higher than in all the other tested treatments. MS medium supplemented with $2.5 \mathrm{mg} / \mathrm{L} \mathrm{2,4-D}$ and $2.5 \mathrm{mg} / \mathrm{L}$ kin was the second best growth regulator combination for the induction of

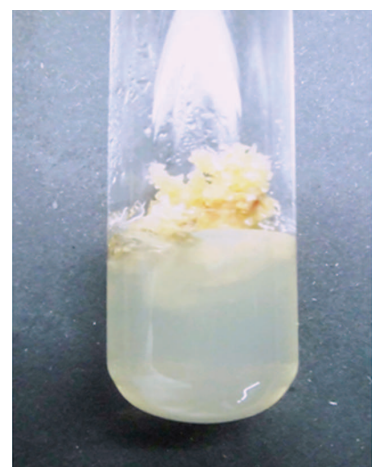

a

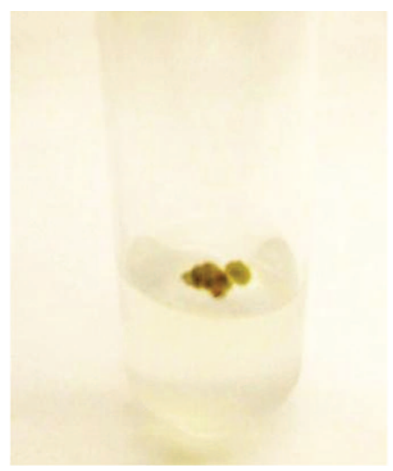

b
Figure 1: Fragile, translucent callus production from a) nodal segments and b) mature seeds in MS medium supplemented with $2.5 \mathrm{mg} / \mathrm{L} 2,4-\mathrm{D}$ and $3.0 \mathrm{mg} / \mathrm{L}$ and kin after 8 weeks of incubation

fragile, translucent callus with a mean callus diameter of $2.91 \pm 0.10 \mathrm{~cm}$. MS medium supplemented with $1.0 \mathrm{mg} / \mathrm{L}$ 2,4-D and $1.0 \mathrm{mg} / \mathrm{L}$ kin showed the least mean callus diameter $(0.63 \pm 0.07 \mathrm{~cm})$ after 8 weeks of incubation (Table 2).

The calli obtained were friable and translucent at the beginning (Figure 2a). After 12 weeks of incubation the calli turned into brownish colour and lost the fragile texture (Figure 2b), since the regenerative capacity of the cells become reduced or is lost totally after a certain period of time.

It was observed that the callus diameter increases with increasing concentration of kin, while it varied differently with the 2,4-D concentration in the medium. It has been

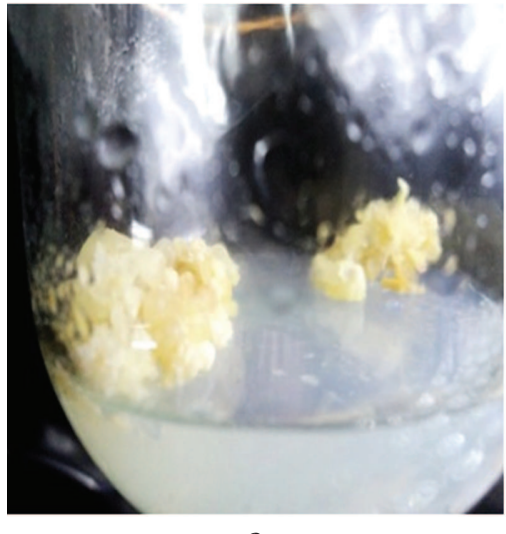

a

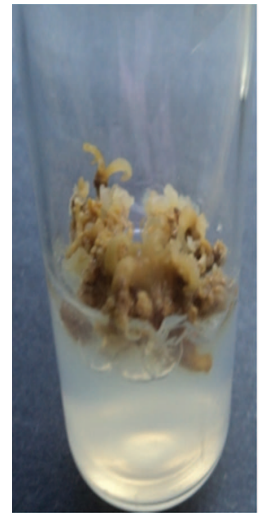

b
Figure 2: a) Fragile viable callus in MS medium supplemented with $2.5 \mathrm{mg} / \mathrm{L} \mathrm{2,} 4-\mathrm{D}$ and $3.0 \mathrm{mg} / \mathrm{L}$ and kin after 8 weeks of incubation and b) change in colour and texture of the same after 12 weeks 
Table 2: Mean callus diameter of embryonic calli from nodal segment explants cultured in MS medium supplemented with different growth regulators after eight weeks of incubation

\begin{tabular}{|c|c|c|c|c|}
\hline \multicolumn{2}{|l|}{$\begin{array}{l}\text { Growth regulator } \\
\text { combination }\end{array}$} & \multicolumn{3}{|c|}{ Mean callus diameter $\pm \mathrm{SE}(\mathrm{cm})$} \\
\hline $2,4-\mathrm{D}: \mathrm{kin}$ & Second week & Fourth week & Sixth week & Eighth week \\
\hline $0.0: 0.0$ & $0.00 \pm 0.00$ & $0.00 \pm 0.00$ & $0.00 \pm 0.00$ & $0.00 \pm 0.00$ \\
\hline $1.0: 1.0$ & $0.28 \pm 0.04$ & $0.40 \pm 0.05$ & $0.52 \pm 0.06$ & $0.63 \pm 0.07$ \\
\hline $1.0: 1.5$ & $0.44 \pm 0.05^{a}$ & $0.60 \pm 0.05$ & $0.76 \pm 0.06$ & $0.97 \pm 0.08$ \\
\hline $1.0: 2.0$ & $0.57 \pm 0.07^{\mathrm{b}}$ & $0.79 \pm 0.07$ & $1.06 \pm 0.08$ & $1.32 \pm 0.08$ \\
\hline $1.0: 2.5$ & $0.53 \pm 0.06$ & $0.72 \pm 0.08$ & $0.99 \pm 0.10$ & $1.25 \pm 0.12$ \\
\hline $1.0: 3.0$ & $0.57 \pm 0.08^{b}$ & $0.75 \pm 0.09$ & $0.94 \pm 0.10$ & $1.17 \pm 0.12$ \\
\hline $1.0: 3.5$ & $0.61 \pm 0.06$ & $0.87 \pm 0.06$ & $1.12 \pm 0.07$ & $1.37 \pm 0.07$ \\
\hline $1.5: 1.0$ & $0.44 \pm 0.04^{a}$ & $0.65 \pm 0.05$ & $0.78 \pm 0.05$ & $0.94 \pm 0.06$ \\
\hline $1.5: 1.5$ & $0.38 \pm 0.05$ & $0.56 \pm 0.05$ & $0.74 \pm 0.06$ & $0.90 \pm 0.06$ \\
\hline $1.5: 2.0$ & $0.36 \pm 0.04$ & $0.52 \pm 0.06$ & $0.62 \pm 0.06$ & $0.81 \pm 0.07$ \\
\hline $1.5: 2.5$ & $0.59 \pm 0.09$ & $0.90 \pm 0.10$ & $1.14 \pm 0.11$ & $1.35 \pm 0.11$ \\
\hline $1.5: 3.0$ & $0.75 \pm 0.09$ & $0.96 \pm 0.10$ & $1.21 \pm 0.11$ & $1.41 \pm 0.11$ \\
\hline $1.5: 3.5$ & $0.79 \pm 0.08$ & $1.06 \pm 0.08$ & $1.31 \pm 0.09$ & $1.60 \pm 0.07$ \\
\hline $2.0: 1.0$ & $0.65 \pm 0.09$ & $1.03 \pm 0.12$ & $1.27 \pm 0.12$ & $1.58 \pm 0.12$ \\
\hline $2.0: 1.5$ & $0.92 \pm 0.11$ & $1.32 \pm 0.12$ & $1.57 \pm 0.13$ & $1.83 \pm 0.16$ \\
\hline $2.0: 2.0$ & $1.16 \pm 0.13$ & $1.52 \pm 0.12^{\mathrm{f}}$ & $1.75 \pm 0.11 \mathrm{i}$ & $1.97 \pm 0.11$ \\
\hline $2.0: 2.5$ & $1.21 \pm 0.14$ & $1.51 \pm 0.15^{\mathrm{f}}$ & $1.82 \pm 0.16$ & $2.08 \pm 0.15$ \\
\hline $2.0: 3.0$ & $1.25 \pm 0.14^{\mathrm{c}}$ & $1.57 \pm 0.12$ & $1.86 \pm 0.11$ & $2.20 \pm 0.10$ \\
\hline $2.0: 3.5$ & $1.35 \pm 0.13^{\mathrm{d}}$ & $1.74 \pm 0.12$ & $2.01 \pm 0.10$ & $2.36 \pm 0.10$ \\
\hline $2.5: 1.0$ & $1.53 \pm 0.15$ & $1.92 \pm 0.15$ & $2.21 \pm 0.12$ & $2.49 \pm 0.11$ \\
\hline $2.5: 1.5$ & $1.83 \pm 0.12$ & $2.11 \pm 0.12^{g}$ & $2.40 \pm 0.11$ & $2.69 \pm 0.12$ \\
\hline $2.5: 2.0$ & $1.75 \pm 0.14$ & $2.22 \pm 0.11$ & $2.56 \pm 0.10^{k}$ & $2.89 \pm 0.08$ \\
\hline $2.5: 2.5$ & $2.04 \pm 0.11$ & $2.31 \pm 0.10$ & $2.55 \pm 0.09^{k}$ & $2.91 \pm 0.10$ \\
\hline $2.5: 3.0$ & $2.11 \pm 0.12$ & $2.41 \pm 0.12$ & $2.77 \pm 0.11$ & $3.22 \pm 0.10$ \\
\hline $2.5: 3.5$ & $1.87 \pm 0.11$ & $2.13 \pm 0.10^{g}$ & $2.32 \pm 0.11$ & $2.51 \pm 0.09$ \\
\hline $3.0: 1.0$ & $1.49 \pm 0.12$ & $1.76 \pm 0.11$ & $1.97 \pm 0.11$ & $2.12 \pm 0.10^{\mathrm{n}}$ \\
\hline $3.0: 1.5$ & $1.26 \pm 0.13^{c}$ & $1.44 \pm 0.10$ & $1.66 \pm 0.13$ & $1.90 \pm 0.14$ \\
\hline $3.0: 2.0$ & $1.39 \pm 0.10$ & $1.66 \pm 0.10^{\mathrm{h}}$ & $1.84 \pm 0.10$ & $2.06 \pm 0.09$ \\
\hline $3.0: 2.5$ & $1.62 \pm 0.10$ & $1.97 \pm 0.09$ & $2.26 \pm 0.06$ & $2.46 \pm 0.07$ \\
\hline $3.0: 3.0$ & $1.15 \pm 0.11$ & $1.45 \pm 0.11$ & $1.67 \pm 0.11$ & $1.88 \pm 0.10$ \\
\hline $3.0: 3.5$ & $1.23 \pm 0.10^{\mathrm{e}}$ & $1.51 \pm 0.10^{\mathrm{f}}$ & $1.78 \pm 0.10$ & $2.04 \pm 0.11$ \\
\hline $3.5: 1.0$ & $1.20 \pm 0.12$ & $1.47 \pm 0.12$ & $1.68 \pm 0.11$ & $1.91 \pm 0.12$ \\
\hline $3.5: 1.5$ & $1.34 \pm 0.07^{\mathrm{d}}$ & $1.58 \pm 0.07$ & $1.78 \pm 0.07$ & $1.99 \pm 0.08$ \\
\hline $3.5: 2.0$ & $1.29 \pm 0.09$ & $1.56 \pm 0.11$ & $1.84 \pm 0.1^{\mathrm{m}}$ & $2.12 \pm 0.11^{\mathrm{n}}$ \\
\hline $3.5: 2.5$ & $1.22 \pm 0.12^{\mathrm{e}}$ & $1.50 \pm 0.13$ & $1.76 \pm 0.1^{\mathrm{m}}$ & $2.02 \pm 0.12$ \\
\hline $3.5: 3.0$ & $1.38 \pm 0.09$ & $1.64 \pm 0.08^{\mathrm{h}}$ & $1.84 \pm 0.0^{\mathrm{m}}$ & $2.00 \pm 0.09$ \\
\hline $3.5: 3.5$ & $1.62 \pm 0.08$ & $1.87 \pm 0.08$ & $2.06 \pm 0.09$ & $2.34 \pm 0.09$ \\
\hline LSD & 0.12 & 0.11 & 0.11 & 0.12 \\
\hline
\end{tabular}

* Measurements are the means of twenty replicates \pm SE

* Means within the columns with the same letter are not significantly different

reported that increased concentrations of 2,4-D up to 2.5 $\mathrm{mg} / \mathrm{L}$ and kin up to $3.0 \mathrm{mg} / \mathrm{L}$ is the best growth regulator combination for callus induction from nodal segments of S. album, which was however affected negatively beyond
$4.0 \mathrm{mg} / \mathrm{L}$ 2,4-D (Bele et al., 2012). In the present study, increased concentrations of 2,4-D over $2.5 \mathrm{mg} / \mathrm{L}$ reduced callus growth similar to the observations of Bele et al. (2012). 


\section{Determination of best growth regulator combination for somatic embryo induction}

Induction of somatic embryos was observed in all tested treatments after two weeks of incubation in the dark at $25 \pm 1{ }^{\circ} \mathrm{C}$. No embryo induction was observed in the growth regulator free MS medium. There was a significant difference between the numbers of somatic embryos induced per callus in different treatments.

After 8 weeks, MS medium supplemented with $0.5 \mathrm{mg} / \mathrm{L} \mathrm{BAP}, 1.0 \mathrm{mg} / \mathrm{L}$ IAA and $0.5 \mathrm{mg} / \mathrm{L}$ kin showed the highest number of somatic embryo induction $(10.20$ \pm 0.66 ) (Figure 3). This was significantly higher than all the other tested treatments (Table 3 ). The least number of somatic embryo induction $(6.93 \pm 0.74)$ was observed in the medium supplemented with $0.25 \mathrm{mg} / \mathrm{L}$ BAP, $0.25 \mathrm{mg} / \mathrm{L}$ IAA and $0.25 \mathrm{mg} / \mathrm{L}$ kin. Somatic embryo induction increased with increasing concentrations of kin, BAP and IAA concentrations but reduced when the concentration of kin exceeded $0.5 \mathrm{mg} / \mathrm{L}$. The results suggest $0.5 \mathrm{mg} / \mathrm{L} \mathrm{BAP,} 1.0 \mathrm{mg} / \mathrm{L} \mathrm{IAA}$ and $0.5 \mathrm{mg} / \mathrm{L} \mathrm{kin}$ as the best growth regulator combination for the induction of somatic embryos from embryonic callus of $S$. album in MS medium. Many embryos were found in scattered clusters upon a large matrix of soft, embryonic calli.

The callus was friable so that the embryos could be easily removed from the callus. Along with regular types of embryos, various abnormal embryos were also observed. The size and the shape of these embryos varied greatly as massive forms and dwarf types of embryos appeared together (Figure 3).

In a study by Rao and Akins (1985) globular embryos formed from protoplast cultures proliferated further and began to form somatic embryos on MS medium supplemented with $1.0 \mathrm{mg} / \mathrm{L}$ IAA and $1.0 \mathrm{mg} / \mathrm{L} \mathrm{BAP}$. Spontaneous somatic embryo induction was observed in the presence of TDZ/BAP with 2,4-D (Rao \& Akins, 1985). Thidiazurone (TDZ) alone and combined with 0.5 and $1.0 \mathrm{mg} / \mathrm{L} \mathrm{2,4-D} \mathrm{were} \mathrm{able} \mathrm{to} \mathrm{induce} \mathrm{somatic}$ embryos. It was found that 2,4-D performed better than naphthalene acetic acid (NAA) (Rugkhla \& Jones, 1998). Differentiation of freshly induced calli takes place in three distinct stages and those are affected by the level of 2,4-D (Rao et al., 1996).

Table 3: The effect of growth regulator combination of BAP, IAA and kin on somatic embryo induction in $1.0 \mathrm{~cm}^{2}$ calli in MS medium after eight weeks of incubation at $25 \pm 1{ }^{\circ} \mathrm{C}$ in complete darkness

\begin{tabular}{cc}
\hline $\begin{array}{c}\text { Growth regulator combination } \\
(\mathrm{mg} / \mathrm{L}) \text { BAP: IAA: kin }\end{array}$ & $\begin{array}{c}\text { Number of somatic embryos } \\
\text { induced per callus } \pm \text { SE }\end{array}$ \\
\hline 0.00: $0.00: 0.00$ & $0.00 \pm 0.00$ \\
0.25: $0.25: 0.25$ & $6.93 \pm 0.76$ \\
0.25: $0.25: 0.50$ & $7.67 \pm 0.70$ \\
0.50: $0.50: 0.25$ & $8.87 \pm 0.58$ \\
0.50: $0.50: 0.50$ & $8.80 \pm 0.46$ \\
0.50: $1.00: 0.25$ & $9.13 \pm 0.91$ \\
0.50: $1.00: 0.50$ & $10.20 \pm 0.66$ \\
$0.50: 1.00: 1.00$ & $8.07 \pm 0.73$ \\
LSD & 0.50 \\
\hline
\end{tabular}

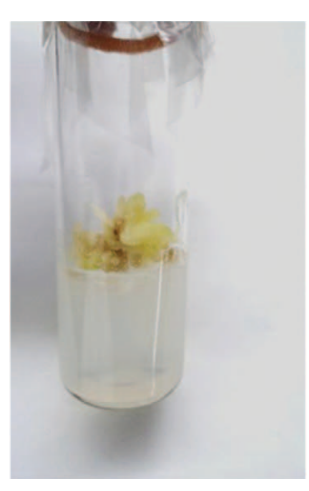

a

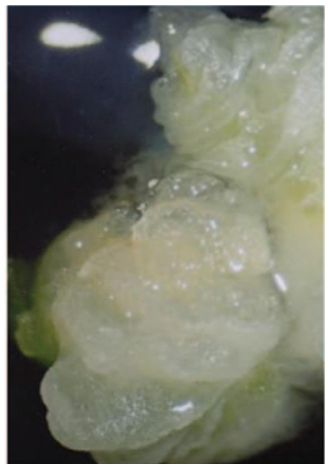

$\mathbf{b}$

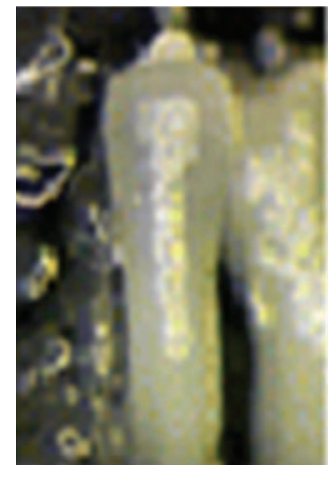

c

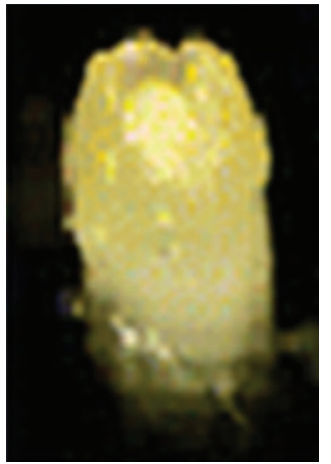

d

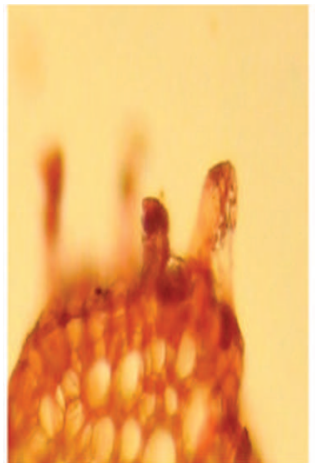

$\mathbf{e}$

Figure 3: a) Embryonic callus; b) induction of somatic embryos; c) elongated somatic embryos; d) germinating embryos and e) cross section of callus with emerging embryos 


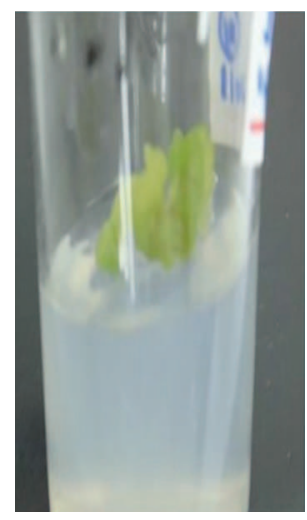

a

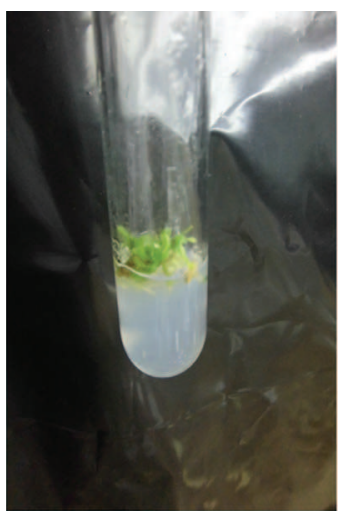

b

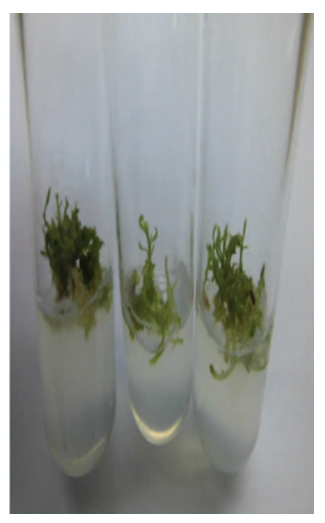

c

Figure 4: Stages of germination of somatic embryos a) somatic embryo initiation in the callus after 8 weeks; b) germination of somatic embryos after 8 weeks and c) growth of somatic embryos into plantlets after 4 weeks

\section{Determination of best growth regulator combination for somatic embryo germination}

Somatic embryo germination was observed in all tested treatments after two weeks of incubation with a 16 hour photoperiod. No embryo germination was observed in growth regulator free MS medium.

There were significant differences between the mean percentages of embryo germination in different treatments. In the medium supplemented with $2.0 \mathrm{mg} / \mathrm{L} \mathrm{GA}_{3}$, the highest mean percentage of embryo germination $(58 \pm 4.13)$ (Figure 4$)$ was observed and this was significantly higher than all the other treatments.

Table 4: Effect of different concentrations of $\mathrm{GA}_{3}$ on percentage of somatic embryo germination after eight weeks of incubation period at $25 \pm 1{ }^{\circ} \mathrm{C}$ with a 16 hour photoperiod

\begin{tabular}{cc}
\hline $\mathrm{GA}_{3}(\mathrm{mg} / \mathrm{L})$ & $\begin{array}{c}\text { Mean somatic embryo } \\
\text { germination } \pm \mathrm{SE}\end{array}$ \\
\hline 0.0 & $00.00 \pm 0.00$ \\
0.5 & $18.00 \pm 3.12$ \\
1.0 & $42.00 \pm 3.27^{\mathrm{a}}$ \\
1.5 & $50.67 \pm 4.41$ \\
2.0 & $58.98 \pm 4.13$ \\
2.5 & $42.00 \pm 4.80^{\mathrm{a}}$ \\
3.0 & $42.67 \pm 4.82$ \\
3.5 & $44.67 \pm 5.29$ \\
$\mathrm{LSD}$ & 3.50 \\
\hline
\end{tabular}

${ }^{*}$ Measurements are the means of twenty replicates $\pm \mathrm{SE}$

* Means within the columns with the same letter are not significantly different
Medium supplemented with $1.5 \mathrm{~g} / \mathrm{L} \quad \mathrm{GA}_{3}$ showed the second highest mean percentage of germination $(50.67 \pm 4.41)$. The lowest germination percentage $(18.00 \pm 3.12)$ was observed in the medium supplemented with $0.5 \mathrm{mg} / \mathrm{L} \mathrm{GA}_{3}$ (Table 4). It is significantly lower than all the other treatments. The results suggest that MS medium supplemented with $2.0 \mathrm{mg} / \mathrm{L} \mathrm{GA}_{3}$ as the best growth regulator combination for somatic embryo germination. Plantlet development from somatic embryos were observed after 3 weeks on both $1 / 2$ MS basal medium or White's medium supplemented with $1.0 \mathrm{mg} / \mathrm{L}$ IAA, $0.5 \mathrm{mg} / \mathrm{L} \mathrm{IBA}$ and $\mathrm{GA}_{3}$ (1.0 and $3.0 \mathrm{mg} / \mathrm{L}$ ) (Bapat \& Rao, 1988), and also in MS medium supplemented with

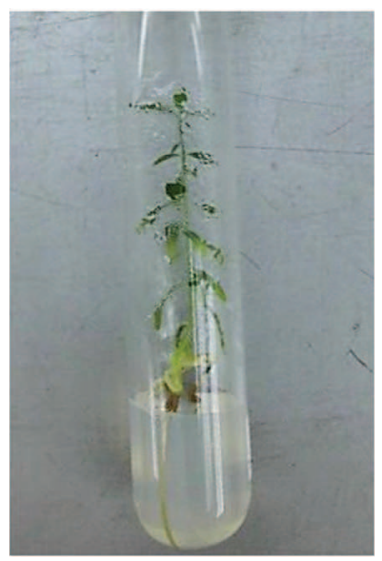

Figure 5: Plantlet developed from a germinated embryo in MS medium supplemented with $0.4 \mathrm{mg} / \mathrm{L}$ BAP and $0.2 \mathrm{mg} / \mathrm{L}$ IAA 
$1.0 \mathrm{mg} / \mathrm{L}$ IAA, $0.5 \mathrm{mg} / \mathrm{L}$ IBA and $10.0 \%$ coconut water (Rao \& Akins, 1985).

Determination of best growth regulator combination for plantlet development from germinated somatic embryos

Plantlet development was observed in all tested treatments within two weeks of incubation in 16 hour photoperiod. There were significant differences between plantlet development in different treatments. Among tested treatments, the medium supplemented with 0.4 $\mathrm{mg} / \mathrm{L}$ BAP and $0.2 \mathrm{mg} / \mathrm{L}$ IAA produced the highest percentage of plantlets $(76.67 \pm 3.03)$ with healthy shoots and roots (Figure 5). MS medium supplemented with $0.6 \mathrm{mg} / \mathrm{L} \mathrm{BAP}$ and $0.2 \mathrm{mg} / \mathrm{L}$ IAA was the second best plant growth regulator combination for plantlet development $(58.67 \pm 4.01)$. The least mean percentage of plantlet development $(44.67 \pm 2.56)$ was observed in the medium supplemented with $0.2 \mathrm{mg} / \mathrm{L}$ BAP and $0.3 \mathrm{mg} / \mathrm{L}$ IAA. According to the results obtained it was observed that when BAP and IAA concentrations are increased, the percentage of plantlet development decreased. The results suggest that $0.4 \mathrm{mg} / \mathrm{L} \mathrm{BAP}$ and 0.2 $\mathrm{mg} / \mathrm{L}$ IAA is the best growth regulator combination for plantlet development from germinated somatic embryos of $S$. album (Table 5).

Table 5: Effect of different combinations of BAP:IAA on the percentage of plantlet development in MS medium after eight weeks of incubation period at $25 \pm 1{ }^{\circ} \mathrm{C}$ with 16 hour photoperiod

\begin{tabular}{cc}
\hline $\begin{array}{c}\text { Growth regulator combination } \\
(\mathrm{mg} / \mathrm{L}) \text { BAP: IAA }\end{array}$ & $\begin{array}{c}\text { Percentage of plantlet } \\
\text { development } \pm \mathrm{SE}\end{array}$ \\
\hline $0.0: 0.0$ & $00.00 \pm 0.00$ \\
$0.2: 0.1$ & $57.33 \pm 5.73$ \\
$0.2: 0.2$ & $46.00 \pm 4.76$ \\
$0.2: 0.3$ & $54.67 \pm 3.89$ \\
$0.2: 0.4$ & $44.67 \pm 2.56$ \\
$0.4: 0.1$ & $55.00 \pm 4.32$ \\
$0.4: 0.2$ & $76.67 \pm 3.03$ \\
$0.4: 0.3$ & $56.67 \pm 3.866^{\text {a }}$ \\
$0.4: 0.4$ & $56.67 \pm 4.22$ a \\
$0.6: 0.1$ & $55.71 \pm 3.75$ \\
$0.6: 0.2$ & $58.67 \pm 4.01$ \\
$0.6: 0.3$ & $56.00 \pm 3.57$ \\
$0.6: 0.4$ & $50.67 \pm 4.22$ \\
LSD & 2.20 \\
\hline & \\
* Measurements are the means of twenty replicates \pm SE \\
Means within the columns with the same letter are not \\
significantly different
\end{tabular}

Some of the plantlets regenerated had well-developed roots and shoots while some were with excellent shoot growth but arrested root growth. Abnormal development of both shoot and root parts has also been observed but the frequency of such plantlets was very low. Plantlets were obtained by culturing the fully developed embryos on basal medium supplemented with $1.0 \mathrm{mg} / \mathrm{L}$ NAA or $1.0 \mathrm{mg} / \mathrm{L}$ IAA (Bapat \& Rao, 1988). Lakshmi et al. (1979) reported embryoid differentiation in shoot callus cultures of $S$. album on a medium supplemented with $\mathrm{GA}_{3}$; however the success rate was low.

\section{CONCLUSION}

The results of the present study indicate that mass propagation of $S$. album is possible through single noded explants obtained from the second or third node of the meristem. Nodal segments have the ability to induce fragile and translucent calli within 10 days of incubation.

A $1.0 \mathrm{~cm}^{2}$ callus could regenerate at least 76 plantlets. As a single node induced nearly $3.0 \mathrm{~cm}$ of callus mass it could be concluded that from a single nodal segment it is possible to obtain at least 230 plantlets after 8 months.

\section{Acknowledgement}

The authors wish to acknowledge the financial assistance granted by the National Science Foundation, under the grant RG/09/BT/02.

\section{REFERENCES}

1. Bapat V.A. \& Rao P.S. (1988). Sandalwood plantlets form "synthetic seeds". Plant Cell Reports 7: $434-436$.

2. Bele D., Tripathi M.K., Tiwari G., Baghel B.S. \& Tiwari S. (2012). Microcloning of sandalwood (Santalum album Linn.) from cultured leaf discs. International Journal of Agricultural Technology 8(2): $571-583$.

3. Jain S.H., Angadi V.G. \& Shankaranarayana K.H. (2003). Edaphic, environmental and genetic factors associated with growth and adaptability of sandal (Santalum album L.) in provenances. Sandalwood Research Newsletter 17: 6-7.

4. Lakshmi S.T., Raghava R.N.V. \& Vaidyanathan C.S. (1979). Differentiation of embryoids and plantlets from shoot callus sandalwood. Plant Science Letters 15: 265 - 270.

5. Mujib A. (2005). In vitro regeneration of Sandal (Santalum album L.) from leaves. Turkish Journal of Botany 29: $63-67$.

6. Murashige T. \& Skoog F. (1962). A revised medium for rapid growth and bio assays with tobacco tissue cultures. Physiologia Plantarum 15(3): 473 - 497.

DOI: http://dx.doi.org/10.1111/j.1399-3054.1962.tb08052.x 
7. Rai S.N. (1990). Status and cultivation of sandalwood in India. USDA Forest Service General Technical Report, pp. $66-71$. USDA Forest Service, Pacific Southwest Research Station, Albany, USA.

8. Rao S.K., Chrungoo N.K. \& Sinha A. (1996). Characterization of somatic embryogenesis in Sandalwood (Santalum album). In vitro Cellular and Developmental Biology - Plant 32: 123 - 128.

DOI: http://dx.doi.org/10.1007/BF02822754

9. Rao P.S. \& Akins P.O. (1985). Plant regeneration through somatic embryogenesis in protoplast cultures of sandalwood (Santalum album L.). Protoplasma 124(1-2): 80 - 86. DOI: http://dx.doi.org/10.1007/BF01279726

10. Rao P.S. \& Bapat V.A. (1992). Micropropagation of sandalwood (Santalum album L.). Biotechnology in
Agriculture and Forestry (ed. Y.P.S. Bajaj), pp. 193 - 210. Springer-Verlag, Berlin, Heidelberg, Germany.

11. Rugkhla A. \& Jones M.G.K. (1998). Somatic embryogenesis and plantlet formation in Santalum album and S. spicatum. Journal of Experimental Botany 49(3): 563 - 571. DOI: http://dx.doi.org/10.1093/jxb/49.320.563

12. Srinivasan V.V., Sivaramakrishnan V.R., Rangaswamy C.R., Ananthapadmanabha H.S. \& Shankaranarayana K.H. (1992). Sandal (Santalum album L.). Proceedings of the Institute of Wood Science and Technology, p. 11. Institute of Wood Science and Technology, Bangalore, India.

13. Viswanath S., Dhanya B. \& Rathore T.S. (2009). Domestication of sandal (Santalum album L.) in India: constraints and prospects. Asia - Pacific Agroforestry Newsletter 34: 9. 